\title{
研究速報
}

\section{遺伝子発現プロファイル類似度としての ピアソン相関係数と相互情報量の比較 \\ Comparison between Pearson Correlation Coefficient and Mutual Information as a Similarity Measure of Gene Expression Profiles}

\author{
法隆大輔*1 ・ 林 武司*1 \\ Daisuke Horyu $^{* 1}$ and Takeshi Hayashi*1 \\ *1 農業・食品産業技術総合研究機構 中央農業総合研究センター \\ ${ }^{* 1}$ NARO Agricultural Research Center \\ e-mail:horyu@affrc.go.jp
}

\begin{abstract}
Definition of similarity is required for clustering co-expressed genes or estimating gene regulatory network from gene expression data. Pearson correlation coefficient and mutual information are the popular measures to evaluate similarity between gene expression profiles. To investigate which measure is appropriate for evaluating similarity between gene expression profiles, we have compared these two measures using Gene ontology annotation similarity. Genes that have similar Gene ontology annotations can be interpreted that they have commonality in biological processes or molecular functions. The results showed that the better similarity measure is different depending on the purpose of the analysis or from which organism the data derived. In the case of evaluating similarities among more than three genes, mutual information was a better similarity measure for the data derived from multicellular organisms, though Pearson correlation coefficient was a better similarity measure for the data derived from unicellular organisms. In the case of finding genes whose transcripts have similar functions or genes that participate to similar processes, Pearson correlation coefficient was always a better measure.
\end{abstract}

Key words: Pearson correlation coefficient, mutual information, gene expression, Gene ontology.

1. はじめに

マイクロアレイや次世代シーケンサなどの分子生物学的技術の発展の結果, ゲノム全体にわたつ て mRNA の発現レベルが測定できるようになったことで，大量の遺伝子発現データが生み出され るようになった．それに伴って，どの遺伝子とどの遺伝子が同じ生物的プロセスに関わっているか といった疑問に答えるため, 遺伝子発現データに対する系統的な解析手法も必要とされるように

Received November 2012. Revised December 2012. Accepted December 2012. 
なった (Brazma and Vilo (2000))。こうした解析手法の主なものとしては，遺伝子ネットワーク の推定 (Bansal et al. (2007)) とクラスタリングによる遺伝子の分類 (D'haeseleer (2005)) が挙げら れる. 遺伝子ネットワークの推定は, 細胞内で起きている遺伝子間相互の調節作用をコンピュー タ上の計算によって遺伝子発現データから復元する手法である. また， クラスタリングによる遺 伝子の分類は, 多数の遺伝子発現パターンの中から類似性の高いものをクラスタにまとめること で，探索的な解析を可能にする手法である．遺伝子ネットワーク推定の一部の方法とクラスタリ ングによる遺伝子の分類の大半の方法では, 最初に遺伝子と遺伝子の間で発現パターン(発現プロ ファイル)間の類似度を評価することになる．このため，2つの発現プロファイルからそれらの間 の類似度を計算する何らかの尺度が必要になる.

このような類似度の尺度としてよく知られているものは, Pearson 相関係数 (PCC) である. 実 際に Eisen et al. (1998) による遺伝子のクラスタリングの研究以来, PCC は発現プロファイル間 の比較尺度として多くの研究で用いられてきた. また，PCC とともに発現プロファイル間の比 較尺度としてよく用いられるのが相互情報量である (Butte and Kohane (2000))。相互情報量は, 情報理論に基づいてデー夕間の依存性を評価する方法である．デー夕間の依存性を評価するため, 線形な関係を評価する PCC では検出できない非線形な関係も検出できる特徵がある. ARACNE (Margolin et al. (2006))のような情報理論に基づく遺伝子ネットワーク推定の方法では, 発現プ ロファイル間の相互情報量を計算することが前提となっている. 具体的な PCC と相互情報量と の傾向の違いを見るために, 図 1 に 4 種類の散布図とそれぞれの PCC と相互情報量の値を示し た. 図 1 の a のうに明らかな線形の関係が見られる場合には, PCC と相互情報量がともに高い 值を示す。 また, 図 1 の b のうに 2 つの変量が独立である場合には, PCC と相互情報量がと もに低い.これらの 2 つのケースでは PCC と相互情報量の間で傾向に違いがない.これに対し て, 図 1 の $\mathrm{c}$ と d のような関係がある場合には, PCCが低い值しか示さない一方, 相互情報量は 高い值を示している．このような関係を検出できることが，相互情報量の利点である．これとは 反対に PCC が高い值を示し，相互情報量は低い值を示す場合もある．そのような例を図 2 に示 した. 図 2 を見ると明らかなように，外れ值がある場合に PCC が高い值を示し，相互情報量は 低い值を示す。しかし，このように外れ值がある場合は PCC が䛊って高い值を示す典型的な例 である. 図 2 の $\mathrm{a}$ と b はそれぞれ, 図 1 の $\mathrm{a}$ と b に外れ值を加えただけのデータであるにも関わ らず，図 2 のbで PCC は高い值を示している，こうした点を考慮すると，図 2 のような場合に 相互情報量が必要な関係を検出できていないという解釈は必ずしも成り立たない.

PCC や相互情報量以外にも Euclid 距離をはじめ様々な尺度が存在する中で, 何が発現プロファ イルの比較尺度として適しているのか, という問題があることは早くから認識されていた (Brazma and Vilo (2000))．PCC と相互情報量の比較においても，それぞれの特性を明らかにする研究が 行われている. Steuer et al. (2002) は, 相互情報量と PCC の双方で評価した発現プロファイル 間の類似度をグラフにプロットした上で, 相互情報量と PCC はほぼ対応関係にあり, 発現プロ ファイル間の関係は基本的に線形であると述べている. Daub et al. (2004) も Steuer et al. (2002) と同様のプロットを行っているが, S.cerevisiae のデータでは発現プロファイル間に非線形な関係 が見られなかったのに対して，ヒトのデータでは非線形な関係が見られるとしている．また，実 
（a） PCC: 0.95, 相互情報量: 1.05

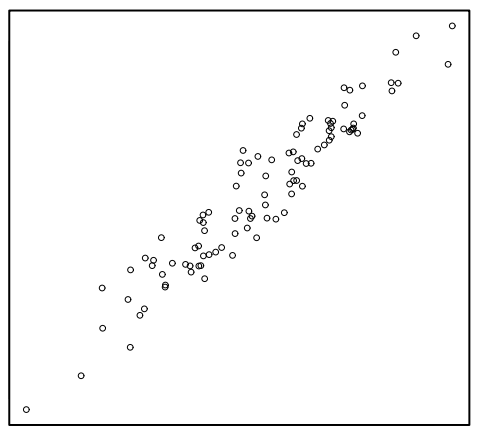

（c） PCC: 0.04, 相互情報量: 0.78

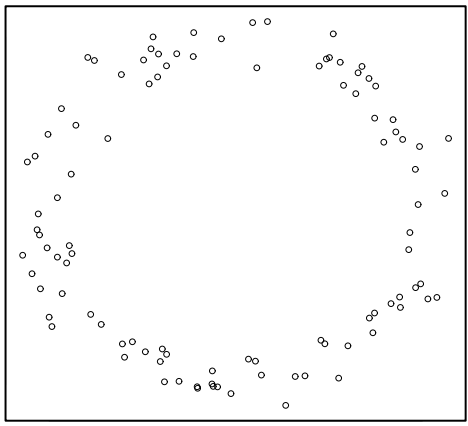

（b） PCC: 0.02, 相互情報量: 0.28

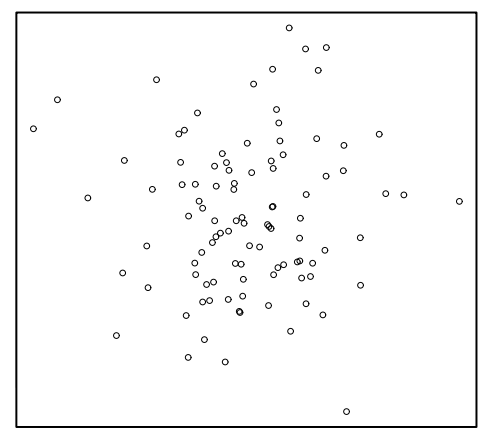

（d） PCC: -0.04 , 相互情報量: 1.11

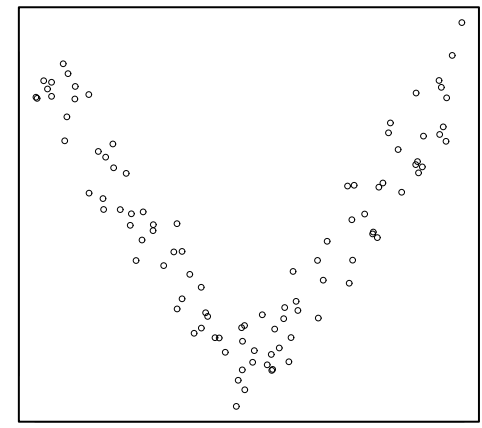

図 1. PCC と相互情報量の傾向の相違

(a)から (d) は, いずれも 100 個の人工的なデータの散布図である. (a) は PCC と相互 情報量がともに高い例, （b) は PCC と相互情報量がともに低い例, (c) と (d) は PCC が 低く相互情報量が高い例を示している. なお, 相互情報量は等幅の binning (材料およ び方法参照)により計算した.

（a） PCC: 0.99, 相互情報量: 0.51

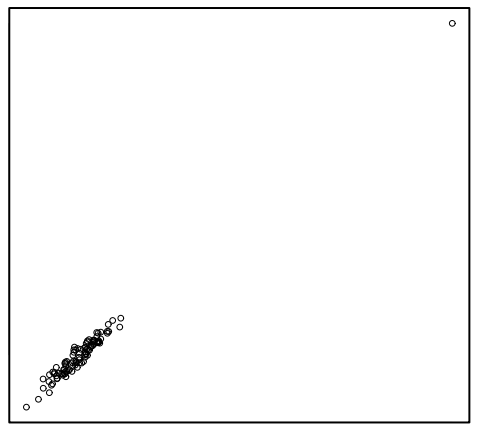

（b） PCC: 0.81, 相互情報量: 0.07

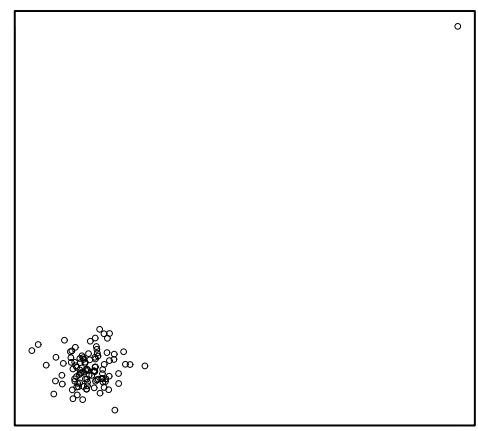

図 2. 外れ值を含む場合の PCC と相互情報量

(a)と（b)は，それぞれ図 1 の (a) と（b)に外れ值を追加した散布図である. なお，相互 情報量は等幅の binning (材料および方法参照)により計算した. 
際に S.cerevisiae の遺伝子ネットワーク構築に用いた例では，相互情報量を用いても PCC を用い た場合と比較して結果が改善しないという報告がある (Lee et al. (2007)).

ここで一つの疑問として，データの由来やデータの利用目的に関わりなく，最適な発現プロファ イルの比較尺度が決められるのか，ということがある. Daub et al. (2004) の結果から， ヒトのよ うに比較的複雑な生物では発現プロファイル間に非線形な関係が存在するのに対して, S.cerevisiae のように比較的単純な生物では発現プロファイル間に非線形な関係が少ない, といつたデータの由 来により非線形性の程度が異なる可能性が示唆される. 非線形性の程度がより大きいならば相互 情報量が PCC より適しているし, 反対に非線形性の程度がより小さいならば相互情報量の PCC に対する優位性は無い。このような疑問に答えるため, 本研究では PCC と相互情報量の比較を 通して, データの由来によって最適な比較尺度が異なるかどうかを検討する. 原核生物と真核生 物, 単細胞生物と多細胞生物, また, 多細胞生物では単独の組織から採られたデー夕と複数の組 織から採られたデータの間で, 最適な尺度に違いがあるかどうか検討する. データの由来だけで なく, 利用目的によっても最適な比較尺度が異なる可能性がある. 例えば, ある一つの遺伝子の みに興味があり，その遺伝子と生物的プロセスに共通性がある遺伝子を見つけることを目的とし て発現プロファイルの類似度を計算することもあれば, クラスタリングを行う場合のように 3 個 以上の遺伝子に興味があり，それらの間の相互の距離関係を評価するために発現プロファイルの 類似度を計算することもある. 本研究ではこれらの 2 つの利用目的とデータの由来との関係につ いても検討を行う.

PCC あるいは相互情報量によって発現プロファイル間の類似度が適切に評価されているかどう かを判断するためには, 何らかの評価手段が必要となる. そのような手段として, 本研究では各 プローブに付与されているジーンオントロジー(GO) (Ashburner et al. (2000))のアノテーション を利用した．転写産物の機能や関わる代謝プロセスなどの情報が知られているか, あるいは推測 できる遺伝子に対しては, GO のタームを用いてその機能や関わる生物的プロセスについての情 報がアノテーションされている. GO は単なるデータベースのアノテーションのための手段とし てだけでなく, クラスタリングの結果の評価 (Gibbons and Roth (2002))などの評価手段としても 利用されている.

発現プロファイル間の類似度を計算するのと同様に, 比較対象となるそれぞれのプローブに対 してアノテーションされた GO のターム群間の類似度が計算できる. GO のターム群間の類似度 は GO のグラフ中での位置の近さを評価することで計算される. もし, ある遺伝子同士の GO の ターム群間の類似度が高ければ，それらの間では機能やプロセスの点で共通性が高いことになる. 2 つの遺伝子の間において, 発現プロファイル間の類似度とアノテーションされた GO のターム 群間の類似度には相関があることは既に知られている (Sevilla et al. (2005)). 発現プロファイル 間の比較を行う目的は, 機能やプロセスの共通性が高い遺伝子を探すことにあり, 機能やプロセ スについての情報を持つアノテーションの類似度を評価基準とすることは, そうした共通性を評 価するという目的に適う. 発現プロファイル間の類似度とアノテーションされた GO のターム群 間の類似度は 1 対 1 に対応するので, 1 個 1 個の発現プロファイル間の類似度に対して, 評価は個 別に与えられる.もし, 発現プロファイル間の類似度が高い組合せに対して, 対応するアノテー 
ションの類似度の值も高ければ，その発現プロファイル間の比較尺度は相対的に良い尺度である と判断できる.

\section{2. 関連する研究}

これまでに発現プロファイルの比較尺度として PCC と相互情報量を比較した研究は, 上でも 述べたように Steuer et al. (2002) と Daub et al. (2004)がある. Steuer et al. (2002) は，様々な 条件の下で測定された 300 件の S.cerevisiae のサンプルを用いて, PCC で評価した発現プロファ イル間の類似度と相互情報量で評価した発現プロファイル間の類似度をプロットしている．その 結果として，PCCによる類似度と相互情報量による類似度は対応しており，純粋に非線形な関係 は存在しないとしている. Daub et al. (2004) は, Steuer et al. (2002) と同じデータセットのほ か, 20 種類のヒトの細胞から得られた 102 件のサンプルを対象として PCC と相互情報量の比較 を行っている．比較は，PCCで評価した発現プロファイル間の類似度と相互情報量で評価した発 現プロファイル間の類似度をプロットすることで行われた. S.cerevisiae のデータセットでは, 発 現プロファイルの間に PCC が見つけられないような非線形な関係は無かつたのに対して，ヒト のデータセットでは非線形な関係があったと述べている.

これらの 2 つの研究以外にも, 発現プロファイルの比較尺度として PCC と相互情報量の比較 を行っていたり, これらの尺度の特徵について言及している研究がある. しかし, 遺伝子間の比 較ではなくサンプル間の比較であったりするなど，いずれも本研究とは目的や手段に異なる点が ある. Ku et al. (2012) は, 発現プロファイルの情報から遺伝子間の制御の関係を識別する際に, 類似度の尺度として PCC と Z スコアに変換した相互情報量を比較している. 様々な条件の下で 観測された 445 件の E.coli の発現プロファイルのデータを用いて, PCC と Z スコアに変換した 相互情報量の值をプロットしている．その上で，既知の遺伝子間相互作用についてのデータベー スの情報から，Zスコアが一定の值以上の組合せでは，それらの遺伝子が共通の因子によって制 御されている可能性が高いとしている. この研究は PCC と相互情報量を比較すること自体が目的 ではないが，遺伝子間ネットワークの構築において PCC が識別できない情報を相互情報量が識別 できる場合があることを示している. Hempel et al. (2011) は, 人工的に生成された短い時系列の 発現プロファイルを用いて遺伝子ネットワークの推定を行い, 21 種類の類似度の尺度を評価して いる. 21 種類の中には PCC と相互情報量も含まれており，この 2 つの尺度の間での比較が可能 な結果もある. しかし, 相互情報量の計算方法は複数あり, また遺伝子ネットワークを推定する 方法, さらに推定された遺伝子ネットワークの評価方法も複数あるため, これらの方法次第で相 互情報量の評価が PCC を上回る場合も下回る場合もあるという結果となっている. PCC と相互 情報量だけの比較が目的ではないこともあり，両者の優劣は判然としない. Usadel et al. (2009) は，遺伝子共発現のツールに関するレビューであるが，その中で遺伝子発現プロファイルの類似 度を評価する尺度として, PCC と相互情報量について言及している，その中で, Arabidopsisの 各組織から選別された 63 件のサンプルをもとにした解析が行われている．その結果として，発現 プロファイル間の類似度で相互情報量が高い值を示し PCC が低い值を示すようなデータはわず かしか無かったと述べている. Priness et al. (2007) は，遺伝子発現プロファイルをもとにしたク 
ラスタの均一性と分離度を評価する尺度として, PCC, Euclid 距離, 相互情報量の比較を行って いる. ただし，この研究では遺伝子間の類似度を計算するのではなく, サンプル間の類似度を計 算するために PCC や相互情報量を用いている. データとしては, ヒトのガン細胞の遺伝子発現 プロファイルを用いている．意図的に誤分類を含むクラスタを作成し，誤分類の少ない場合と誤 分類の多い場合でクラス夕の均一性と分離度の值に差が出るかどうかという観点で, これらの尺 度を評価した。 その結果, 相互情報量を用いた場合に均一性と分離度の值の差が大きく, 相互情 報量が誤分類に対する感度が最も高いことを明らかにしている.

\section{3. 材料および方法}

\section{1 データセット}

解析に供した発現プロファイルデータの詳細を表 1 に示した. 6 種類の生物についてそれぞ れ 2 個ずつ, 合計 12 個のデータセットを用いた. 生物学的な区分としては, E.coli と S.aureus が原核生物で単細胞生物, S.cerevisiae が真核生物で単細胞生物, A.thaliana, D.melanogaster, M.musculus が真核生物で多細胞生物である. 多細胞生物の場合には, 単独の組織から採られた サンプルのみで構成されたデータセットと複数の組織から採られたサンプルで構成されたデータ セットがあるが, 複数の組織から採られたサンプルで構成されたデータセットでは, 組織ごとの 発現量に非線形な関係があり，非線形な関係も評価できる相互情報量に有利に働く可能性がある. このことを考慮して, 多細胞生物のデータセットとしては, 単独の組織から採られたサンプルの みで構成されたデータセットと複数の組織から採られたサンプルで構成されたデータセットの両 方を使用した.

データは全て GEO (Barrett et al. (2011)) からダウンロードしたものである. 各 CEL ファイルの

表 1. 解析に使用した発現データ

\begin{tabular}{lllll}
\hline データセット名 & 生物種 & データソース & 標本数 & 採取対象組織 \\
\hline E.coli-1 & Escherichia coli & GSE6836 & 266 & - \\
E.coli-2 & Escherichia coli & GSE15406 & 24 & - \\
S.aureus-1 & Staphylococcus aureus & GSE15394 & 37 & - \\
S.aureus-2 & Staphylococcus aureus & GSE22233 & 30 & - \\
Yeast-1 & Saccharomyces cerevisiae & GSE25582 & 151 & - \\
Yeast-2 & Saccharomyces cerevisiae & GSE15254 & 72 & - \\
Arabidopsis-1 & Arabidopsis thaliana & GSE5629,GSE5630,GSE5631 & 237 & 複数 \\
& & GSE5632,GSE5633,GSE5634 & & \\
Arabidopsis-2 & Arabidopsis thaliana & GSE22966 & 36 & 単独 \\
Drosophila-1 & Drosophila melanogaster & GSE7763 & 120 & 複数 \\
Drosophila-2 & Drosophila melanogaster & GSE23802 & 54 & 単独 \\
Mouse-1 & Mus musculus & GSE10246 & 182 & 複数 \\
Mouse-2 & Mus musculus & GSE11685 & 32 & 単独 \\
\hline
\end{tabular}


データはRMA（Irizarry et al. (2003)) により正規化した. この RMA による正規化は Bioconductor (Gentleman et al. (2004))のライブラリ affy を利用して行った. プローブの中には, 常に発現し ているか，またはほとんど発現していないなど発現量の変化がそしいものも多い。このように変 化の乏しいデータの比較には実用上の意味が乏しいため，解析から除外した．具体的には，正規 化した後の各プローブの最大の発現量と最小の発現量の差を求め, 各データセットの中で差が大 きいプローブ 3 分の 1 のみを解析対象とした. また, 発現プロファイルの類似度を評価する際に, GO のアノテーションの類似度を評価基準として利用するため, GO のアノテーションが無いプ ローブは解析の対象から除外した.

\section{2 発現プロファイル間の類似度}

発現プロファイル間の類似度の計算は PCC と相互情報量を用いて行った. 連続值の相互情報 量を計算するためには, 周辺確率と同時確率を推定する必要があり, そのために様々な計算や補 正の方法が提案されている (Meyer et al. (2008)). 本研究では, 等幅の binning による方法と k最近隣法 (kNN) （Kraskov et al. (2004))の 2 種類を用いた. 等幅の binning は相互情報量の計算 法として一般的で, 発現量の変域を幾つかの等幅の小区間に分割してヒストグラムを作成する方 法である. $\mathrm{kNN}$ も発現量の変域に小区間を作成するが，小区間の幅は対象となるサンプルに最も 近い $k$ 個のサンプルを用いて決定し, 小区間同士が重複することもある.

$N$ 個のサンプルからなる発現プロファイル $\mathbf{x}=\left(x_{1}, x_{2}, \ldots, x_{N}\right)$ と $\mathbf{y}=\left(y_{1}, y_{2}, \ldots, y_{N}\right)$ の間で, 等幅の binning による相互情報量は次の通り計算される. まず, $\mathbf{x}$ の変域を同じ大きさの $k$ 個の 区間に分割したとき， $\mathbf{x}$ のうち $i$ 番目の区間に入る数を $n_{i}$ とすれば，周辺確率 $p_{i}$ は

$$
p_{i}=\frac{n_{i}}{N}
$$

によって近似できる. 同様に $\mathbf{y} も k$ 個の区間に分割すれば, 周辺確率 $p_{j}$ および同時確率 $p_{i j}$ が求 められる．これらを用いると等幅の binning による相互情報量は

$$
r_{\text {binning }}=\sum_{i=1}^{k} \sum_{j=1}^{k} p_{i j} \log \frac{p_{i j}}{p_{i} p_{j}}
$$

で与えられる．分割する区間の数 $k$ は事前に与える必要があるが， Priness et al. (2007) を参考

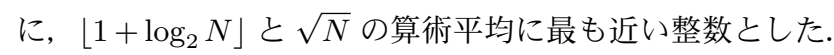

一方, $\mathrm{kNN}$ による相互情報量は次の通り計算される. $N$ 個のサンプルからなる発現プロファイ ル $\mathrm{x}$ と $\mathrm{y}$ の間で, あるサンプル $\left(x_{i}, y_{i}\right)$ から最も近い $k$ 個のサンプルの集合を $S_{i}$ とする. ただ し, サンプル $\left(x_{i}, y_{i}\right)$ から別のサンプル $\left(x^{\prime}, y^{\prime}\right)$ までの距離は

$$
\max \left(\left|x^{\prime}-x_{i}\right|,\left|y^{\prime}-y_{i}\right|\right)
$$

で定義する. このとき, 小区間の大きさ $\varepsilon_{x}(i)$ と $\varepsilon_{y}(i)$ を

$$
\begin{aligned}
& \varepsilon_{x}(i)=\max \left\{\left|x^{\prime}-x_{i}\right| \mid\left(x^{\prime}, y^{\prime}\right) \in S_{i}\right\} \\
& \varepsilon_{y}(i)=\max \left\{\left|y^{\prime}-y_{i}\right| \mid\left(x^{\prime}, y^{\prime}\right) \in S_{i}\right\}
\end{aligned}
$$

とし, $\left|x_{i}-x_{j}\right| \leq \varepsilon_{x}(i)$ である点 $\left(x_{j}, y_{j}\right)$ の個数を $n_{x}(i), \quad\left|y_{i}-y_{j}\right| \leq \varepsilon_{y}(i)$ である点 $\left(x_{j}, y_{j}\right)$ の個 数を $n_{y}(i)$ とすると, $\mathrm{kNN}$ による相互情報量は

Jpn J Biomet Vol. 33, No. 2, 2012 


$$
r_{k N N}=\psi(k)-\frac{1}{k}-\frac{1}{N} \sum_{i=1}^{N}\left\{\psi\left(n_{x}(i)\right)+\psi\left(n_{y}(i)\right)\right\}+\psi(N)
$$

で与えられる. ただし， $\psi(x)$ はディガンマ関数である. $\mathrm{kNN}$ ではパラメータとして近隣の点の 数 $k$ を設定する必要があるが, ここでは 5 に設定した.

\section{3 アノテーション間の類似度}

GO は 'regulation of transcription', 'protein folding’などといったタームとそれらを繋ぐノー ドを要素とする有向非循環グラフであり, Biological Process (BP), Cellular Component (CC), Molecular Function（MF）の 3 つの体系から構成される.この体系の中でお互いに近くに位置す るターム同士は類似度が高いとするのが, ターム間の類似度の基本的な考え方である. 本研究で のターム間の類似度の計算は Wang et al. (2007) の方法に基づいて行った. この方法では, ター ム間の類似度はグラフの中での上位のタームの共通性を評価することで計算する. 上位のターム に共通なものが多ければ，体系の中で近くに位置している，すなわち類似度が高いと判断される. あるターム $A$ に対して, 直接, 間接の上位にあたるタームと $A$ 自身の集合を $T_{A}$ とする. このと き, $T_{A}$ に属するターム $t$ に対して, 次のように $S_{A}(t)$ を定義する.

$$
S_{A}(t)=\max \left(w \times S_{A}\left(t^{\prime}\right)\right)
$$

ここで， $t^{\prime}$ は $t$ の子にあたるタームで， $S_{A}(A)=1$ である. また， $w$ はターム間のノードに対す る重みで, ノードが is-a の場合に 0.8 , part-of の場合に 0.6 とした. この $S_{A}(t)$ は $A$ から上位の タームに行くほど值が小さくなり，他のタームとの間で上位のタームの共通性を評価する際に， $A$ に近いものほど重みが大きくなる性質を持つ. $S_{A}(t)$ を用いれば, $2 \supset$ つーム $A$ と $B$ の間で の類似度 $S_{G O}(A, B)$ は,

$$
S_{G O}(A, B)=\frac{\sum_{t \in T_{A} \cap T_{B}}\left(S_{A}(t)+S_{B}(t)\right)}{\sum_{t^{\prime} \in T_{A}} S_{A}\left(t^{\prime}\right)+\sum_{t^{\prime \prime} \in T_{B}} S_{B}\left(t^{\prime \prime}\right)}
$$

により計算される.この $S_{G O}(A, B)$ によって, 1 個のタームともう 1 個のタームとの間の類似度 が計算できる. しかし, 実際には 1 個のプローブに複数のタームがアノテーションされている場 合も多い. したがって, プローブ同士のアノテーションの類似度を決めるためには, 複数のター ム群の間での類似度が必要になる. 2 つのプローブに対してアノテーションされているターム群 $G O_{1}=\left\{g o_{11}, g o_{12}, \ldots, g o_{1 m}\right\}$ と $G O_{2}=\left\{g o_{21}, g o_{22}, \ldots, g o_{2 n}\right\}$ に対して, 類似度は

$$
s\left(G O_{1}, G O_{2}\right)=\frac{\sum_{i=1}^{m} \max _{1 \leq j \leq n}\left(S_{G O}\left(g o_{1 i}, g o_{2 j}\right)\right)+\sum_{j=1}^{n} \max _{1 \leq i \leq m}\left(S_{G O}\left(g o_{1 i}, g o_{2 j}\right)\right)}{m+n}
$$

で定義される.このターム群間の類似度は $(0,1]$ の值をとる. GO は BP, CC, MF の 3 つの体系 から構成されているが，アノテーション間の類似度はこれらの体系ごとに別々に計算される。も し BP での類似度に注目すれば，生物的なプロセスの観点からプローブ間の類似度を評価してい ることになり，MF の類似度に注目すれば，転写によって生産されるタンパク質の機能の観点か らプローブ間の類似度を評価していることになる, といった使い分けができる. なお，実際のア 
ノテーション間の類似度の計算には, 2011 年 11 月時点の RDF-XML 形式の GO のファイルをダ ウンロードして使用した.

\section{4. 結 果}

\section{1 実 験 1}

発現プロファイル間の類似度を用いる場面の一つとして, 遺伝子のクラスタリングのように 3 個以上の遺伝子に興味があり，それらの相互の距離関係を評価したい場合がある．発現プロファ イル間の類似度を大きい方から小さい方へ順に並べた時に, 対応する組合せでのアノテーション 間の類似度も徐々に小さくなれば，その発現プロファイル間の類似度は，機能やプロセスについ ての情報を正しく評価できていることに相当する. したがって，発現プロファイル間の類似度と アノテーション間の類似度の相関が高ければ，発現プロファイル間の類似度を評価する尺度とし て適していると考えることができる. しかし，全てのプローブの間でのデータを用いて相関を直 接計算してしまうと, 極めて低い相関しか見られないことが分かっている (Sevilla et al. (2005)). このため, 発現プロファイル間の類似度の值をソートした上で, 同数のデータを含む小区間に分 け, 各小区間に含まれるデータの発現プロファイルの類似度の中央值とアノテーションの類似度 の中央値を用いて，相関を評価することにした.

全体で $N$ 個のプローブから成るデータセットにおいて, $i$ 番目のプローブと $j(j \neq i)$ 番目のプ ローブの間での発現プロファイルの類似度を $r_{i j}$, アノテーションの類似度を $s_{i j}$ とする.

全てのプローブの間での類似度の組合せ

$$
\left\{\left(r_{12}, s_{12}\right),\left(r_{13}, s_{13}\right), \ldots,\left(r_{N-1 N}, s_{N-1 N}\right)\right\}
$$

について, $r_{(1)}>r_{(2)}>\cdots>r_{\left(\frac{N(N-1)}{2}\right)}$ となるよう並べ替えたものを

$$
\left\{\left(r_{(1)}, s_{(1)}\right),\left(r_{(2)}, s_{(2)}\right), \ldots,\left(r_{\left(\frac{N(N-1)}{2}\right)}, s\left(\frac{N(N-1)}{2}\right)\right)\right\}
$$

とする.これを同数のデータを持つ 100 個の小区間に分け，小区間ごとに中央值

$$
\begin{gathered}
r_{b i n}(1)=\operatorname{med}\left(r_{(1)}, r_{(2)}, \ldots, r_{\left(\left\lfloor\frac{1}{100} \times \frac{N(N-1)}{2}\right\rfloor\right)}\right) \\
r_{b i n}(2)=\operatorname{med}\left(r_{\left(\left\lfloor\frac{1}{100} \times \frac{N(N-1)}{2}\right\rfloor+1\right), r}\left(\left\lfloor\frac{1}{100} \times \frac{N(N-1)}{2}\right\rfloor+2\right), \ldots, r\left(\left\lfloor\frac{2}{100} \times \frac{N(N-1)}{2}\right\rfloor\right)\right) \\
\vdots \\
r_{b i n}(100)=\operatorname{med}\left(r_{\left(\left\lfloor\frac{99}{100} \times \frac{N(N-1)}{2}\right\rfloor+1\right)}, r_{\left(\left\lfloor\frac{99}{100} \times \frac{N(N-1)}{2}\right\rfloor+2\right)}, \ldots, r\left(\frac{N(N-1)}{2}\right)\right)
\end{gathered}
$$

を計算する. $(9)$ 式から $(11)$ 式と同様に $s_{b i n}(1), s_{b i n}(2), \ldots, s_{b i n}(100)$ を計算し, $r_{b i n}(k)$ と $s_{b i n}(k)$ と の間で Spearmanの順位相関係数 $\rho$ を計算した. 図 3 に $\left(r_{b i n}(1), s_{b i n}(1)\right)$ から $\left(r_{b i n}(100), s_{b i n}(100)\right)$ までをプロットした例を示す．この図の例での順位相関係数は $\rho=0.990$ と比較的高い.もし発 現プロファイル間の類似度が適切に評価できていれば，言い換えるとその発現プロファイルを評 価する尺度がそのデータに適したものであれば，この図の例のように発現プロファイル間の類似 度とアノテーション間の類似度は高い相関を示す．なお PCC の場合, PCC が 1 に近い時にアノ テーション間の類似度が高く, PCC が 0 に近づくにつれてアノテーション間の類似度が下がるこ Jpn J Biomet Vol. 33, No. 2, 2012 


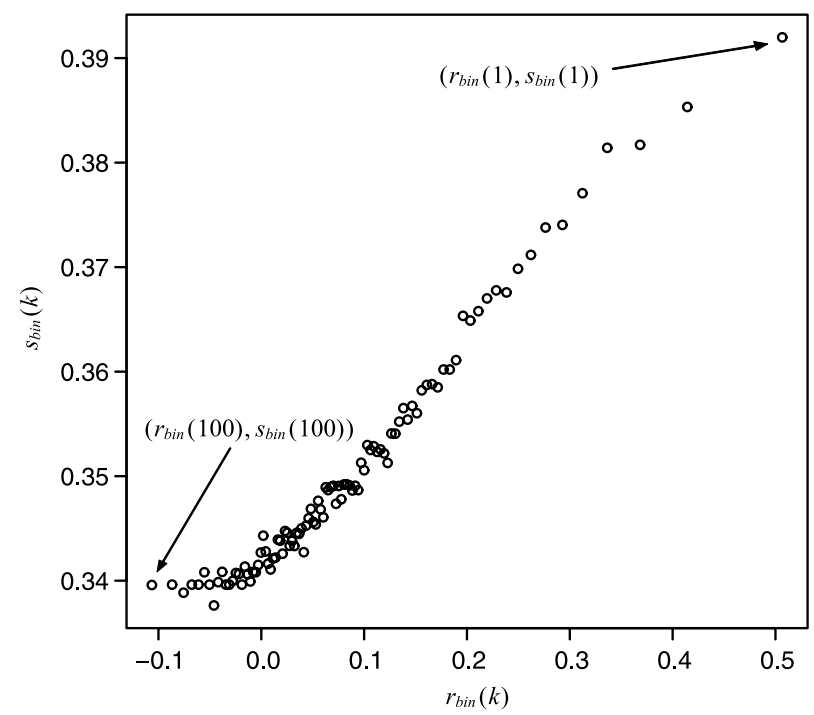

図 3. 発現プロファイル間の類似度とアノテーション間の類似度の関係 データセットとして Drosophila-2 を用い, アノテーション間の類似度は MF で, 発現プロファイル間の類似度は $\mathrm{kNN}$ で計算した場合の $\left(r_{b i n}(1), s_{b i n}(1)\right)$ から $\left(r_{b i n}(100), s_{b i n}(100)\right)$ までをプロットしたもの. このデータでの順位相 関係数は $\rho=0.990$ である.

とが期待される. さらに, PCCが 0 から -1 に近づくと発現プロファイル間に負の相関があるた め, アノテーション間の類似度も再び上がることが期待される. 順位相関係数 $\rho$ ではこのように いったん減少した後に増加する関係は正しく評価できない.このため PCC に関しては, 最初に $r_{i j}$ を正の值と負の值に分けた上で上記の手順で $\rho$ を計算した.

表 2 は順位相関係数 $\rho$ の值をまとめたものである. データセットおよび GO の区分ごとにどの 比較尺度が最大值を示すかを見ると, 表の上半分の単細胞生物と表の下半分の多細胞生物で傾向 が異なることが分かる. E.coli-1 から Yeast-2 まで，すなわち単細胞生物の場合には PCC の正の 值で順位相関係数が最大值を示す場合が多かった.これに対して, Arabidopsis-1 から Mouse-2 までの多細胞生物では $\mathrm{kNN}$ を用いた場合に順位相関係数が最大值を示す場合が多い. 今回の実 験の対象としたデータセットの間では，アノテーションとの相関の高い尺度が異なる場合があっ た. そうした違いの傾向を生物種の観点から見ると, 単細胞生物と多細胞生物との間でアノテー ションとの相関の高い尺度に違いが見られるという傾向であった. 単独の組織から採取されたデー タセットについて見ると, Mouse-2 で単細胞生物と同様に PCC の正の值で順位相関係数が最大 值を示した. 一方で単独の組織から採取されたデータでも Arabidopsis-2 と Drosophila-2 では, $\mathrm{kNN}$ を用いた場合に順位相関係数が最大值を示す場合が多く, 複数の組織から採取されたデー タセットと同様の傾向であった。このように単独の組織から採取されたデータでは傾向が分かれ た.

また, 生物種や組織の観点だけではなく, サンプル数が与える影響についても考慮する必要が 
表 2. $r_{b i n}(k)$ と $s_{b i n}(k)$ の間の順位相関係数

\begin{tabular}{|c|c|c|c|c|}
\hline データセット名 & 尺度 & $\mathrm{BP}$ & $\mathrm{CC}$ & $\mathrm{MF}$ \\
\hline \multirow[t]{4}{*}{ E.coli-1 } & $\operatorname{PCC}\left(r_{i j}>0\right)$ & 0.946 & 0.831 & 0.913 \\
\hline & $\operatorname{PCC}\left(r_{i j}<0\right)$ & 0.561 & 0.688 & 0.719 \\
\hline & binning & 0.862 & 0.865 & 0.760 \\
\hline & $\mathrm{kNN}$ & 0.872 & 0.677 & 0.895 \\
\hline \multirow[t]{4}{*}{ E.coli-2 } & $\operatorname{PCC}\left(r_{i j}>0\right)$ & 0.978 & 0.153 & 0.977 \\
\hline & $\operatorname{PCC}\left(r_{i j}<0\right)$ & 0.440 & -0.441 & 0.010 \\
\hline & binning & 0.876 & 0.102 & 0.953 \\
\hline & $\mathrm{kNN}$ & 0.925 & -0.322 & 0.975 \\
\hline \multirow[t]{4}{*}{ S.aureus-1 } & $\operatorname{PCC}\left(r_{i j}>0\right)$ & 0.641 & 0.705 & 0.647 \\
\hline & $\operatorname{PCC}\left(r_{i j}<0\right)$ & -0.713 & 0.305 & 0.144 \\
\hline & binning & 0.146 & 0.106 & 0.518 \\
\hline & $\mathrm{kNN}$ & 0.208 & 0.189 & 0.782 \\
\hline \multirow[t]{4}{*}{ S.aureus-2 } & $\operatorname{PCC}\left(r_{i j}>0\right)$ & 0.847 & 0.875 & 0.963 \\
\hline & $\operatorname{PCC}\left(r_{i j}<0\right)$ & 0.381 & -0.804 & 0.791 \\
\hline & binning & 0.749 & 0.628 & 0.965 \\
\hline & $\mathrm{kNN}$ & 0.566 & 0.545 & 0.983 \\
\hline \multirow[t]{4}{*}{ Yeast-1 } & $\operatorname{PCC}\left(r_{i j}>0\right)$ & -0.025 & 0.566 & 0.945 \\
\hline & $\operatorname{PCC}\left(r_{i j}<0\right)$ & 0.137 & -0.141 & -0.078 \\
\hline & binning & 0.372 & 0.613 & 0.272 \\
\hline & $\mathrm{kNN}$ & -0.659 & 0.348 & 0.766 \\
\hline \multirow[t]{4}{*}{ Yeast-2 } & $\operatorname{PCC}\left(r_{i j}>0\right)$ & 0.907 & 0.862 & 0.945 \\
\hline & $\operatorname{PCC}\left(r_{i j}<0\right)$ & 0.775 & 0.066 & -0.671 \\
\hline & binning & -0.585 & 0.510 & -0.924 \\
\hline & $\mathrm{kNN}$ & -0.443 & 0.755 & -0.690 \\
\hline
\end{tabular}

太字はその区分の 4 種類の尺度の中で最大の值を示している.

ある. Daub et al. (2004) でも報告されているように，相互情報量はサンプル数が少ない場合には 推定の誤差が大きく, サンプル数が増加するに従い推定が改善する. こうしたサンプル数の多少 による影響は表 2 の結果にも現れている．例えば，サンプル数 266 の E.coli-1，サンプル数 237 の Arabidopsis-1, サンプル数 182 の Mouse-1 など, サンプル数の多いデータセットで相互情報 量とアノテーションは高い相関を示している.このようなサンプル数の多少による影響は, 次の ような観測される相互情報量 $I_{\mathrm{obs}}$ の標準誤差 $S E\left(I_{\mathrm{obs}}\right)$ の式(Roulston (1999)) に起因するもので ある。

$$
S E\left(I_{\mathrm{obs}}\right)=\sqrt{\frac{1}{N} \sum_{i=1}^{k} \sum_{j=1}^{k}\left(\ln p_{i}+\ln p_{j}-\ln p_{i j}+I_{\mathrm{obs}}\right)^{2} p_{i j}\left(1-p_{i j}\right)}
$$

ここで， $N$ はサンプル数， $k$ は分割された区間の数， $p_{i}$ と $p_{j}$ はそれぞれ周辺確率， $p_{i j}$ は同時確 率である. 式 (12) は, サンプル数 $N$ の増加にともなって $S E\left(I_{\mathrm{obs}}\right)$ が小さくなり，結果として相 Jpn J Biomet Vol. 33, No. 2, 2012 
表 2. $r_{b i n}(k)$ と $s_{b i n}(k)$ の間の順位相関倸数 (続き)

\begin{tabular}{|c|c|c|c|c|}
\hline データセット名 & 尺度 & $\mathrm{BP}$ & $\mathrm{CC}$ & MF \\
\hline \multirow[t]{4}{*}{ Arabidopsis-1 } & $\operatorname{PCC}\left(r_{i j}>0\right)$ & 0.986 & 0.985 & 0.777 \\
\hline & $\operatorname{PCC}\left(r_{i j}<0\right)$ & 0.041 & -0.947 & -0.178 \\
\hline & binning & 0.999 & 0.985 & 0.982 \\
\hline & $\mathrm{kNN}$ & 0.999 & 0.992 & 0.995 \\
\hline \multirow[t]{4}{*}{ Arabidopsis-2 } & $\operatorname{PCC}\left(r_{i j}>0\right)$ & 0.710 & 0.916 & 0.835 \\
\hline & $\operatorname{PCC}\left(r_{i j}<0\right)$ & -0.857 & 0.184 & -0.310 \\
\hline & binning & 0.777 & 0.839 & 0.794 \\
\hline & $\mathrm{kNN}$ & 0.185 & 0.944 & 0.943 \\
\hline \multirow[t]{4}{*}{ Drosophila-1 } & $\operatorname{PCC}\left(r_{i j}>0\right)$ & 0.972 & 0.974 & 0.987 \\
\hline & $\operatorname{PCC}\left(r_{i j}<0\right)$ & -0.750 & 0.829 & 0.202 \\
\hline & binning & 0.994 & 0.994 & 0.994 \\
\hline & $\mathrm{kNN}$ & 0.965 & 0.998 & 0.995 \\
\hline \multirow[t]{4}{*}{ Drosophila-2 } & $\operatorname{PCC}\left(r_{i j}>0\right)$ & 0.640 & 0.981 & 0.694 \\
\hline & $\operatorname{PCC}\left(r_{i j}<0\right)$ & -0.555 & 0.783 & 0.912 \\
\hline & binning & 0.058 & 0.916 & 0.958 \\
\hline & $\mathrm{kNN}$ & 0.825 & 0.949 & 0.990 \\
\hline \multirow[t]{4}{*}{ Mouse-1 } & $\operatorname{PCC}\left(r_{i j}>0\right)$ & 0.999 & 0.999 & 0.998 \\
\hline & $\operatorname{PCC}\left(r_{i j}<0\right)$ & 0.879 & 0.966 & 0.948 \\
\hline & binning & 1.000 & 1. 000 & 1.000 \\
\hline & $\mathrm{kNN}$ & 0.999 & 1.000 & 1.000 \\
\hline \multirow[t]{4}{*}{ Mouse-2 } & $\operatorname{PCC}\left(r_{i j}>0\right)$ & 0.993 & 1.000 & 0.997 \\
\hline & $\operatorname{PCC}\left(r_{i j}<0\right)$ & 0.416 & -0.417 & -0.852 \\
\hline & binning & 0.806 & 0.986 & 0.041 \\
\hline & $\mathrm{kNN}$ & 0.988 & 0.998 & 0.994 \\
\hline
\end{tabular}

太字はその区分の 4 種類の尺度の中で最大の值を示している.

互情報量の推定が改善することを意味している. この式から, 表 2 の結果に対して, サンプル数 が多いデータセットで相互情報量の推定が改善した結果, 相互情報量とアノテーションの相関が 高くなつたという説明を与えることができる. 反対に, サンプル数の少ないデータセットの場合 には, 相互情報量を推定する際の誤差が大きかったため, アノテーションとの相関を低くしてし まっている可能性がある.

また，データセット固有の事情が影響していると推測される結果もある. Yeast-2 では BP, CC, $\mathrm{MF}$ ともに PCC とアノテーションの相関が 1 に近い值を示しているにも関わらず, 相互情報量 とアノテーションの相関は負の相関を示したり，低い相関しか示していない. 図 2 で示したよう に，PCC だけが検出できる関係は外れ值がある場合などに限られ，相互情報量とアノテーショ ンの相関が PCC とアノテーションの相関に比べて大幅に悪いということは考えにくい. Yeast-2 は，栄養欠乏により多数の遺伝子の発現が変化しているデータセットである. こうした発現の変 
化の結果として本来のプロセスあるいは機能的な類似度に関わりなく, これら多数の遺伝子の間 で相互情報量の值が上昇し，アノテーションとの相関が低下してしまったと考えられる．このよ うなデータセット固有の事情は全てのデータセットが本質的に有しているものであり, 表 2 で見 られた傾向が直ちに一般のデータにも当てはまると考えるべきではない.

多細胞生物のデー夕においては $\mathrm{kNN}$ が PCC を上回ることが多かったが, binning と PCC の 正の值との比較では binning に優位性はなかった.このことから，少なくとも相互情報量の計算 では単純な binning より $\mathrm{kNN}$ を用いるべきであることが分かる．ただし，相互情報量の計算法お よび補正法は様々なものが提案されており, その中で $\mathrm{kNN}$ が発現プロファイルの比較尺度とし て最も適しているかどうかは別途検討すべき課題である. BP, CC, MF の間では明確な傾向は見 られなかった．すなわち，発現プロファイルから，その遺伝子が関わるプロセスの距離関係を評 価するのか, 機能の距離関係を評価するのか, といつた観点による比較尺度の優劣に関する傾向 は確認できなかった.

\section{2 実 験 2}

発現プロファイル間の類似度を用いる別の場面として, 特定の 1 個の遺伝子に注目しその遺伝 子と機能やプロセスの観点で共通性が高い遺伝子を探したい場合がある．ある遺伝子と発現プロ ファイル間の類似度が高い遺伝子が, アノテーション間の類似度で見ても高い值を示す場合，そ の比較尺度は発現プロファイル間の類似度を評価することで, 機能やプロセスの共通性が高い遺 伝子を見つけていることに相当する．これを検証するため，それぞれの比較尺度で発現プロファ イル間の類似度を計算し，上位に位置づけられた遺伝子について，アノテーション間の類似度を 比較することにした.

全体で $N$ 個のプローブから成るデータセットにおいて, $i$ 番目のプローブと $j(j \neq i)$ 番目のプ ローブの間での発現プロファイルの類似度を $r_{i j}$, アノテーションの類似度を $s_{i j}$ とする.

$i$ 番目のプローブと他の全てのプローブの間での類似度の組合せ

$$
\left\{\left(r_{i 1}, s_{i 1}\right),\left(r_{i 2}, s_{i 2}\right), \ldots,\left(r_{i N-1}, s_{i N-1}\right)\right\}
$$

について, $r_{i(1)}>r_{i(2)}>\cdots>r_{i(N-1)}$ となるよう並べ替えたものを

$$
\left\{\left(r_{i(1)}, s_{i(1)}\right),\left(r_{i(2)}, s_{i(2)}\right), \ldots,\left(r_{i(N-1)}, s_{i(N-1)}\right)\right\}
$$

とする. このとき, ある順位 $k$ に注目して $s_{(k)}$ を

$$
s_{(k)}=\operatorname{med}\left(s_{1(k)}, s_{2(k)}, \ldots, s_{N(k)}\right)
$$

とし，その $s_{(k)}$ の $m$ 位までの平均を

$$
\bar{s}_{(m)}=\frac{1}{m} \sum_{l=1}^{m} s_{(l)}
$$

とする. 実験 2 では, 各データセットについて, (13) 式から $\bar{s}_{(m)}$ を計算した. 図 4 に同じデー タセットに対して PCC, binning, $\mathrm{kNN}$ それぞれで $\bar{s}_{(1)}$ から $\bar{s}_{(100)}$ までを計算した結果を示した. いずれの尺度でも順位が下がるにつれて $\bar{s}_{(m)}$ が低下する傾向が見られ, 発現プロファイルの類似 度の高い遺伝子は機能の面から見ても類似度が高いことが分かる.このような傾向は, BP, CC, Jpn J Biomet Vol. 33, No. 2, 2012 


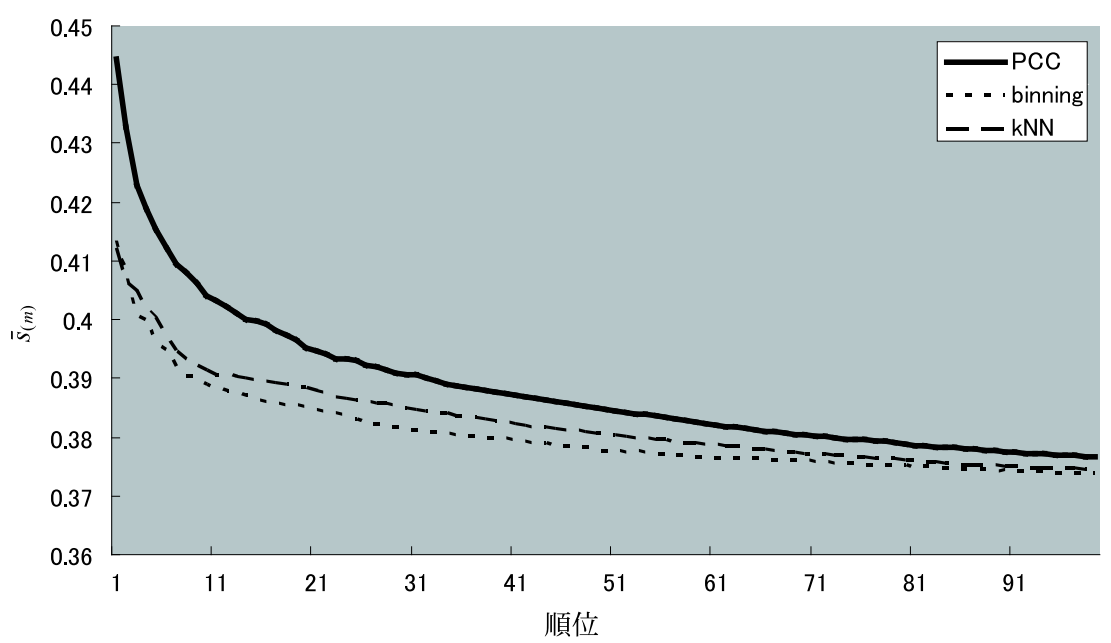

図 4. 発現プロファイル間類似度が上位の組合せにおけるアノテーション間類似度 データセットとして Drosophila-1 を用い, アノテーション間の類似度は MF で計算し た場合について, PCC, binning, $\mathrm{kNN}$ それぞれの $\bar{s}_{(1)}$ から $\bar{s}_{(100)}$ までをグラフ化した もの.

MF の区分や生物種に関わりなく, 他のデータセットでも共通していた. また, 同じ順位で比較 した場合, 図 4 では他の 2 つの尺度と比べて PCC でアノテーション間の類似度が高い. したがつ て, このデータセットの場合には PCC が他の 2 つの尺度に比べて, 機能の類似度が高い遺伝子を 見つけることに適していると言える. なお， $s_{(m)}$ ではなく, $\bar{s}_{(m)}$ を比較している理由としては, $s_{(m)}$ は順位ごとの変動が大きく頻繁に尺度の間で上下が入れ替わり, 傾向を把握することが難し いためである. また, 個別の遺伝子から見ると, 図 4 のように順位が下がるにつれて $s_{i j}$ の值が 下がる傾向は明確なものではなく, $s_{i j}$ の高い遺伝子が上位に点在する結果となる. しかし, $\bar{s}_{(m)}$ として見ることで $s_{i j}$ の高い遺伝子をどの程度上位に位置づけることができているかが把握でき るようになる.

各データセットに対して $\bar{s}_{(10)}$ と $\bar{s}_{(100)}$ を計算した結果を, 表 3 にまとめた. 同じデータセット の同じ GO の区分の中では, $\bar{s}_{(10)}$ と $\bar{s}_{(100)}$ が高い尺度の方が機能やプロセスの類似度が高い遺伝 子を見つけることに適していることになる. 10 位までの平均でも, 100 位までの平均でも, ほと んどのデータにおいて, PCC を用いた場合にアノテーションの類似度が高いことが分かる. この ように実験 1 の結果と異なり, 生物種による傾向の違いは見られなかった.このことは, 類似度 を計算する目的によっても最適な尺度が異なることを示している. 尺度の間での比較には直接関 係しなかったが，類似度の值には幾つかの傾向が見られる．例えば， CC でアノテーション間の 類似度が BP や MF と比べて高くなる傾向がある.これは GO の中で定義されている CC のター 厶数が 3,000 程度しかなく, 20,000 を超えるタームがある BP などと比べて, 結果的にアノテー ションが似てしまうことを反映していると推測される. また, 同じ生物種の中で見ると, サンプ ル数の多いデータセットでアノテーションの類似度が高くなる傾向がある. この傾向は, 情報が 増えることにより, 発現プロファイル間の類似度が機能やプロセスの共通性を正確に反映するよ 
表 3. アノテーションの類似度の平均值

\begin{tabular}{|c|c|c|c|c|c|c|c|}
\hline \multirow[b]{2}{*}{ データセット名 } & \multirow[b]{2}{*}{ 尺度 } & \multicolumn{3}{|c|}{$\bar{s}_{(10)}$} & \multicolumn{3}{|c|}{$\bar{s}_{(100)}$} \\
\hline & & BP & $\mathrm{CC}$ & MF & BP & $\mathrm{CC}$ & MF \\
\hline \multirow[t]{3}{*}{ E.coli-1 } & PCC & 0.163 & 0.362 & 0.234 & 0.129 & 0.300 & 0.201 \\
\hline & binning & 0.151 & 0.318 & 0.231 & 0.125 & 0.290 & 0.204 \\
\hline & $\mathrm{kNN}$ & 0.155 & 0.310 & 0.233 & 0.125 & 0.292 & 0.205 \\
\hline \multirow[t]{3}{*}{ E.coli-2 } & PCC & 0.124 & 0.290 & 0.201 & 0.116 & 0.284 & 0.191 \\
\hline & binning & 0.116 & 0.284 & 0.192 & 0.113 & 0.284 & 0.189 \\
\hline & $\mathrm{kNN}$ & 0.120 & 0.284 & 0.198 & 0.114 & 0.283 & 0.190 \\
\hline \multirow[t]{3}{*}{ S.aureus-1 } & PCC & 0.290 & 0.640 & 0.373 & 0.225 & 0.548 & 0.333 \\
\hline & binning & 0.244 & 0.604 & 0.353 & 0.215 & 0.539 & 0.327 \\
\hline & $\mathrm{kNN}$ & 0.265 & 0.626 & 0.368 & 0.218 & 0.542 & 0.328 \\
\hline \multirow[t]{3}{*}{ S.aureus-2 } & PCC & 0.265 & 0.691 & 0.409 & 0.243 & 0.613 & 0.379 \\
\hline & binning & 0.247 & 0.611 & 0.394 & 0.237 & 0.561 & 0.374 \\
\hline & $\mathrm{kNN}$ & 0.257 & 0.630 & 0.401 & 0.240 & 0.560 & 0.375 \\
\hline \multirow[t]{3}{*}{ Yeast-1 } & PCC & 0.258 & 0.669 & 0.507 & 0.240 & 0.638 & 0.486 \\
\hline & binning & 0.257 & 0.661 & 0.507 & 0.237 & 0.630 & 0.478 \\
\hline & $\mathrm{kNN}$ & 0.259 & 0.665 & 0.510 & 0.237 & 0.629 & 0.481 \\
\hline \multirow[t]{3}{*}{ Yeast-2 } & PCC & 0.259 & 0.658 & 0.509 & 0.243 & 0.637 & 0.481 \\
\hline & binning & 0.241 & 0.646 & 0.484 & 0.229 & 0.626 & 0.453 \\
\hline & kNN & 0.249 & 0.657 & 0.490 & 0.234 & 0.634 & 0.460 \\
\hline
\end{tabular}

太字はその区分の 3 種類の尺度の中で最大の值を示している.

うになつた結果として説明できる. 実験 1 で見られたようなサンプル数の相互情報量への影響と しては，Yeast-1 と Arabidopsis-1 において kNN が PCC を上回る場合が複数あったことに注目 する必要がある.それぞれ，151 件，237 件といずれもサンプル数の多いデータセットであり，実 験 2 の場合においてもサンプル数は結果に影響を与えていると考えられる.

\section{5. 考 察}

生物種や利用目的によって最適な発現プロファイルの比較尺度が異なる可能性について，これ までは断片的な情報しか得られていなかつた。本研究では, 6 種類の生物種からのデー夕を使つ た 2 種類の実験によって, PCC と相互情報量の比較を行った。 その結果, 実験 1 では取り扱う データがどの生物種に由来するかによって PCC が適している場合と kNN が適している場合があ るのに対して, 実験 2 ではデー夕の種類に関わりなく, PCC の方が適していることが分かった. このように本研究を通して, データがぞのような生物種に由来しているかという点から見ても, また利用目的やサンプル数によっても最適な比較尺度が常に同じとは限らないことが示唆された. 今回使用したのは限られた数のデータセットのみであり，また上で述べた Yeast-2 の場合のよう にデータセット固有の事情が影響を与えている結果もある．実際には様々なタイプのデータセッ トがあり得る中で，ここで見られた傾向が直ちに他のデータセットにあてはまるとは言えないが, Jpn J Biomet Vol. 33, No. 2, 2012 
表 3. アノテーションの類似度の平均值 (続き)

\begin{tabular}{|c|c|c|c|c|c|c|c|}
\hline \multirow[b]{2}{*}{ データセット名 } & \multirow[b]{2}{*}{ 尺度 } & \multicolumn{3}{|c|}{$\bar{s}_{(10)}$} & \multicolumn{3}{|c|}{$\bar{s}_{(100)}$} \\
\hline & & $\mathrm{BP}$ & $\mathrm{CC}$ & MF & $\mathrm{BP}$ & $\mathrm{CC}$ & MF \\
\hline \multirow[t]{3}{*}{ Arabidopsis-1 } & PCC & 0.204 & 0.575 & 0.326 & 0.192 & 0.546 & 0.311 \\
\hline & binning & 0.202 & 0.547 & 0.319 & 0.194 & 0.525 & 0.309 \\
\hline & $\mathrm{kNN}$ & 0.206 & 0.543 & 0.326 & 0.198 & 0.524 & 0.312 \\
\hline \multirow[t]{3}{*}{ Arabidopsis-2 } & PCC & 0.191 & 0.514 & 0.327 & 0.185 & 0.505 & 0.318 \\
\hline & binning & 0.184 & 0.503 & 0.317 & 0.180 & 0.496 & 0.312 \\
\hline & $\mathrm{kNN}$ & 0.185 & 0.507 & 0.319 & 0.180 & 0.501 & 0.313 \\
\hline \multirow[t]{3}{*}{ Drosophila-1 } & PCC & 0.222 & 0.511 & 0.404 & 0.198 & 0.464 & 0.376 \\
\hline & binning & 0.203 & 0.482 & 0.389 & 0.188 & 0.454 & 0.374 \\
\hline & $\mathrm{kNN}$ & 0.202 & 0.470 & 0.391 & 0.186 & 0.448 & 0.374 \\
\hline \multirow[t]{3}{*}{ Drosophila-2 } & PCC & 0.186 & 0.492 & 0.380 & 0.178 & 0.476 & 0.371 \\
\hline & binning & 0.176 & 0.472 & 0.381 & 0.170 & 0.462 & 0.371 \\
\hline & $\mathrm{kNN}$ & 0.180 & 0.478 & 0.378 & 0.172 & 0.466 & 0.371 \\
\hline \multirow[t]{3}{*}{ Mouse-1 } & PCC & 0.249 & 0.632 & 0.453 & 0.201 & 0.573 & 0.400 \\
\hline & binning & 0.223 & 0.605 & 0.445 & 0.193 & 0.557 & 0.405 \\
\hline & $\mathrm{kNN}$ & 0.223 & 0.600 & 0.443 & 0.192 & 0.554 & 0.402 \\
\hline \multirow[t]{3}{*}{ Mouse-2 } & PCC & 0.205 & 0.635 & 0.435 & 0.195 & 0.612 & 0.417 \\
\hline & binning & 0.193 & 0.590 & 0.415 & 0.188 & 0.576 & 0.407 \\
\hline & $\mathrm{kNN}$ & 0.199 & 0.606 & 0.425 & 0.191 & 0.586 & 0.410 \\
\hline
\end{tabular}

太字はその区分の 3 種類の尺度の中で最大の值を示している.

今後の比較尺度の選択において生物種やサンプル数, 利用目的を考慮すべきであることは明らか になった.

実験 2 の結果を見ても分かるように, PCC は多くの場合において優れた比較尺度であると言 えるが, 多細胞生物の発現プロファイルの間には PCC では正確に評価されない非線形な関係が あり，それを評価できるかどうかが実験 1 の結果に影響を与えたものとみられる．比較尺度の優 劣を検討する研究では, 単細胞生物のデータが使われることもある. 例えば, Steuer (2002) が発 現プロファイル間の関係は基本的に線形である, と述べているのは単細胞生物の S.cerevisiaeの デー夕を用いて解析を行った結果についてである. しかし, そのような単細胞生物のデータでは 相互情報量での評価に適した非線形な関係が少なく，相互情報量に不利に働くバイアスがある可 能性も否定できないため, 解釈に注意が必要である.

実験 1 の単細胞生物のデータで高い相関を示したのは, PCC の正の值であった. しかし, 発現 プロファイル間で PCC を計算した場合，当然ながら負の值が生じることもある．PCC の負の值 は, 単細胞生物でも低い相関しか示さなかった. また, 単細胞生物のデータでは相互情報量も低 い相関を示す場合が多く，代替手段としては十分でない．このような場合にどの尺度をもちいる

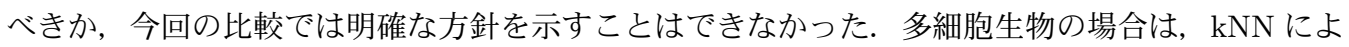
る相互情報量が高い相関を示したので，このような問題は生じない。また，実験 2 のように PCC 
の正の值の一部だけを用いる場合も, PCC の負の值についての問題は生じない.

多細胞生物の場合でも, Mouse-2 のデータセットでは BP, CC, MF の全てにおいて, PCC の正 の值で相関係数が最大值を示した. このように, 単独の組織から採取されたデータでは PCCの 正の值が適している場合があるかもしれない. しかし, Mouse-2 のデータセットでは, kNNも 1 に近い相関係数を示していること, 加えて PCC も負の值では相関係数がマイナスの值を示す場 合があること, などを考慮する必要がある.こうした点を考えれば, 多細胞生物のデータでは, 単独の組織から採取されたデー夕に対しても $\mathrm{kNN}$ を比較尺度として用いて差し支えない.もつ とも, このような単独の組織から採取されたデータは, シンプルな時系列データである場合が多 い. そのような時系列データに対しては，PCC や相互情報量のように時間ごとの測定データを前 後関係に関わりなく評価する方法より, 時間軸から見た発現量の変化を幾つかのパターンに分け, パターンの共通性をもとにプローブ間の類似度を評価する方法が適していることが分かっている (Hempel et al. (2011)).

他の研究との関係を見ると, 実験 1 の結果は, 単細胞生物であるS.cerevisiae のデータでは発 現プロファイル間に非線形な関係は無く, 多細胞生物であるヒトのデータでは非線形な関係が見 られるとする Daub et al. (2004) の結果と一致する. 多細胞生物のデータに非線形な関係が存在 するために, 実験 1 では多細胞生物由来のデータセットにおいて kNN の相関係数が PCC のそ れを上回ったと解釈できる. Daub et al. (2004) では, ヒトのデータには PCCでは捉えられてい ない非線形な関係が存在するということだけが分かっていた．本研究の結果では，これに加えて $\mathrm{kNN}$ とアノテーションの相関が高いことが分かった. このことから, 多細胞生物の発現プロファ イルにおける非線形な関係が，機能やプロセスの観点からも意味のある関係だということが分かつ た. 一方で Usadel et al. (2009) の見解と本研究の結果とは整合しない可能性がある. 実験 1 では Arabidopsis を含めた多細胞生物のデータセットにおいて $\mathrm{kNN}$ の相関係数が PCC の相関係数を 上回る場合が多く，非線形な関係が存在すると推測された. これに対して, Usadel et al. (2009) では, Arabidopsis のデータにおいて発現プロファイル間の類似度で相互情報量が高い值を示し PCCが低い值を示すようなデー夕はわずかであったと述べている. このような不整合の理由は明 らかでないが, Usadel et al. (2009) で述べているのは, 図 1 の c や d に相当するような違いの明 白なデータが少ないということであるかもしれない.もしそうであれば，そのような一部のデー タが, 実験 1 で評価した発現プロファイル間の類似度とアノテーション間の類似度との相関に与 える影響は限られており, 不整合は生じていないと言える.

\section{参考文献}

Ashburner, M., Ball, C. A., Blake, J. A., Botstein, D., Butler, H., Cherry, J. M., Davis, A. P., Dolinski, K., Dwight, S. S., Eppig, J. T., Harris, M. A., Hill, D. P., Issel-Tarver, L., Kasarskis, A., Lewis, S., Matese, J. C., Richardson, J. E., Ringwald, M., Rubin, G. M. and Sherlock, G. (2000). Gene ontology: tool for the unification of biology. Nature Genetics 25, 25-29.

Bansal, M., Belcastro, V., Ambesi-Impiombato, A. and di Bernardo, D. (2007). How to infer gene networks from expression profiles. Molecular Systems Biology 3, 78. 
Barrett, T., Troup, D. B., Wilhite, S. E., Ledoux, P., Evangelista, C., Kim, I. F., Tomashevsky, M., Marshall, K. A., Phillippy, K. H., Sherman, P. M., Muertter, R. N., Holko, M., Ayanbule, O., Yefanov, A. and Soboleva, A. (2011). NCBI GEO: archive for functional genomics data sets-10 years on. Nucleic Acids Research 39, D1005-D1010.

Brazma, A. and Vilo, J. (2000). Gene expression data analysis. FEBS Letters 480, 17-24.

Butte, A. J. and Kohane, I. S. (2000). Mutual information relevance networks: functional genomic clustering using pairwise entropy measurements. Pacific Symposium on Biocomputing 5, $415-426$.

Daub, C. O., Steuer, R., Selbig, J. and Kloska, S. (2004). Estimating mutual information using Bspline functions - an improved similarity measure for analysing gene expression data. $B M C$ Bioinformatics 5, 118 .

D'haeseleer, P. (2005). How does gene expression clustering work? Nature Biotechnology 23, 1499-1501.

Eisen, M. B., Spellman, P. T., Brown, P. O. and Botstein, D. (1998). Cluster analysis and display of genome-wide expression patterns. Proceedings of the National Academy of Sciences of the United States of America 95, 14863-14868.

Gentleman, R. C., Carey, V. J., Bates, D. M., Bolstad, B., Dettling, M., Dudoit, S., Ellis, B., Gautier, L., Ge, Y., Gentry, J., Hornik, K., Hothorn, T., Huber, W., Iacus, S., Irizarry, R., Leisch, F., Li, C., Maechler, M., Rossini, A. J., Sawitzki, G., Smith, C., Smyth, G., Tierney, L., Yang, J. Y. and Zhang, J. (2004). Bioconductor: open software development for computational biology and bioinformatics. Genome Biology 5, R80.

Gibbons, F. D. and Roth, F. P. (2002). Judging the quality of gene expression-based clustering methods using gene annotation. Genome Research 12, 1574-1581.

Hempel, S., Koseska, A., Nikoloski, Z. and Kurths, J. (2011). Unraveling gene regulatory networks from time-resolved gene expression data - a measures comparison study. BMC Bioinformatics 12, 292 .

Irizarry, R.A., Hobbs, B., Collin, F., Beazer-Barclay, Y. D., Antonellis, K. J., Scherf, U. and Speed, T.P. (2003). Exploration, normalization, and summaries of high density oligonucleotide array probe level data. Biostatistics 4, 249-264.

Kraskov, A., Stögbauer, H. and Grassberger, P. (2004). Estimating mutual information. Physical Review E 69, 066138.

Ku, W. L., Duggal, G., Li, Y., Girvan, M. and Ott, E. (2012). Interpreting patterns of gene expression: signatures of coregulation, the data processing inequality, and triplet motifs. PLoS ONE 7, e31969. 
Lee, I., Li, Z. and Marcotte, E. M. (2007). An improved, bias-reduced probabilistic functional gene network of baker's yeast, Saccharomyces cerevisiae. PLoS ONE 2, e988.

Margolin, A. A., Nemenman, I., Basso, K., Wiggins, C., Stolovitzky, G., Dalla Favera, R. and Califano, A. (2006). ARACNE: an algorithm for the reconstruction of gene regulatory networks in a mammalian cellular context. BMC Bioinformatics 7, S7.

Meyer, P. E., Lafitte, F. and Bontempi, G. (2008). minet: A R/Bioconductor package for inferring large transcriptional networks using mutual information. BMC Bioinformatics 9, 461.

Priness, I., Maimon, O. and Ben-Gal, I. (2007). Evaluation of gene-expression clustering via mutual information distance measure. BMC Bioinformatics 8, 111.

Roulston, M. S. (1999). Estimating the errors on measured entropy and mutual information. Physica D 125, 285-294.

Sevilla, J. L., Segura, V., Podhorski, A., Guruceaga, E., Mato, J. M., Martínez-Cruz, L. A., Corrales F. J. and Rubio A. (2005). Correlation between gene expression and GO semantic similarity. IEEE/ACM Transactions on Computational Biology and Bioinformatics 2, 330338.

Steuer, R., Kurths, J., Daub, C. O., Weise, J. and Selbig, J. (2002). The mutual information: detecting and evaluating dependencies between variables. Bioinformatics 18, S231-S240.

Usadel, B., Obayashi, T., Mutwil, M., Giorgi, F. M., Bassel, G. W., Tanimoto, M., Chow, A., Steinhauser, D., Persson, S., Provart, N. J. (2009). Co-expression tools for plant biology: opportunities for hypothesis generation and caveats. Plant, Cell and Environment 32, 16331651.

Wang, J. Z., Du, Z., Payattakool, R., Yu, P. S. and Chen, C. F. (2007). A new method to measure the semantic similarity of GO terms. Bioinformatics 23, 1274-1281. 